\title{
EFFECT OF TERMINAL HIGH TEMPERATURE IMPOSED BY LATE SOWING ON PHENOLOGICAL TRAITS OF WHEAT
}

\author{
M. Ilias Hossain ${ }^{1}$, M.R.I Mondal' ${ }^{2}$, M. J. Islam³ ${ }^{3}$ M A Hakim ${ }^{4}$ and M.K. Sultan ${ }^{5}$ \\ ${ }^{1}$ Senior Scientific Officer (Agronomy), ${ }^{3}$ Scientist Officer, Regional Wheat Research Centre, BARI, Rajshahi \\ ${ }^{2}$ Director General, ${ }^{5}$ Director (Research), Bangladesh Agricultural Research Institute, Gazipur \\ ${ }^{4}$ Senior Scientific Officer, Wheat Research Centre, BARI, Dinajpur \\ Corresponding author E-mail: iliasrwrc@gmail.com
}

Key words: Sowing dates, wheat genotypes, temperature, phenological traits \& yield

\begin{abstract}
Phenological performance in relation to yield of wheat genotypes; BARI Gom 26, BAW 1051, BARI Gom 27 and BARI Gom 28 were evaluated under normal and heat stress environments. One irrigated timely sowing (ITS) and three irrigated late sowings (ILS) were imposed to provide terminal high temperature over the tested genotypes. The ITS was November 25 and three ILS were December 10, December 25 and January 10. In heat stress condition, the genotypes phased a significant level of high temperature stress which affected on phenological stage and yield compared to ITS. In ITS situation, days to anthesis and booting decreased in heat stress condition regardless the cultivars. The phenological characteristics under heat stressed condition led the wheat cultivars to significantly lower grain yield as compared to normal condition. In heat stress situations (Dec 10-Jan 10), the average grain yield was reduced by12.8 $39.8 \%$ in BARI Gom 26, 14.4-29.7\% in BAW 1051, 11.5-26.5\% in BARI Gom 27 and 17.4-25.6\% in BARI Gom 28 in both the season. It was also observed that grain yield was found to be reduced by about $7.7-15.4 \%$ in BARI Gom 26, 9.4-15.7 \% in BAW 1051, 9.4-12.4\% in BARI Gom 27 and 9.7-12.0\% in BARI Gom 28 from ITS for each $1 \mathrm{C}$ rise in average mean air temperature during booting to maturity. On the other hand, reduction percent were less for the new varieties. Grain yield reduction was about $1.4-2.65 \%$ in BARI Gom 28, 0.1-6.7 \% in BARI Gom 27 and 1.7-6.0\% in BAW 1051.
\end{abstract}

\section{Introduction}

Developing heat tolerant wheat variety is a demand of the hour in Bangladesh due to global warming or climate change. It is known to all that wheat seed sowing optimum time is from 15 November to 30 November in the country whether in Northern part of Bangladesh is up to 7 December due to cool weather compared to that of other parts of the country. Generally, the farmer of the country cultivates wheat in winter season after harvesting of $T$. Aman Rice. But due to adverse weather farmers cannot transplant $\mathrm{T}$. Aman rice timely, ultimately harvests delayed. So, it is not possible for farmers to sow wheat seed timely. Most of the farmers sow wheat seed on December, even in later i.e in January. Late sowing wheat genotypes faced high temperature. As a result, heat stress due to late sowing beyond certain limits lowers the grain yield significantly. Researchers have pointed out that wheat yield is considerably affected by sowing date (Chio et al., 1992; Liszewski, 1999; Michiyama et al., 1998; Pecio and Wielgo, 1999). In fact, due to variation of sowing date the ambient temperature vary widely which affects the phenology of any crop plant. Temperature is a modifying factor in all stages including germination, tillering, booting, ear emergence, anthesis and maturity since it can 
Hossain et al.

influence the rate of water supply and other substrate necessary for growth (Wanjura and Buxtor, 1972). Under the high temperature, the wheat crop completes its life cycle much faster than under normal temperature conditions (Fischer, 1985). Plant responses to high temperature vary with plant species, variety and phenological stages. Reproductive processes are markedly affected by high temperatures in most plants, which ultimately affect fertilization and post-fertilization processes leading to reduced crop yield (Wahid et al., 2007). Thus, for crop production under high temperatures, it is important to know the developmental stages and plant processes that are most sensitive to heat stress as well as whether high day or high night temperatures are more injurious. In such context, Wheat Research Centre, BARI is supposed to develop high yielding wheat variety (HYV) considering their suitability in the existing cropping systems or environment. Accordingly, WRC developed some suitable variety (s) having heat tolerant which can be grown after harvest of T. Aman. As plant responses to high temperature vary with plant species, variety, location and phenological stages, it is essential to observe the performance of the promising or advanced genotypes of wheat in respect of phonological traits. Considering the views in mind, the trial was undertaken to find out heat tolerant suitable variety (s) of wheat with its suitable sowing times in adverse climate condition with higher yield.

\section{Materials and Methods}

The experiment was carried out in the rabi season of 2012-13 and 2013-14 in research field of Regional Wheat Research Centre, Rajshahi of Bangladesh Agricultural Research institute. The soil of the experimental field of Rajshahi belongs to AEZ \# 11 characterized by flood free highland, fine in texture (Sandy loam and Silty loam) and poor in organic matter content. The experiment was laid out in split-plot design with 3 replications. Three wheat varieties and one advanced genotypes $\left(\mathrm{V}_{1}\right.$ : BARI Gom 26, $\mathrm{V}_{2}$ : BAW 1051, $\mathrm{V}_{3}$ : BARI Gom 27 and $\mathrm{V}_{4}$ : BARI Gom 28) and BARI Gom 26 was used as test crop. One irrigated timely sowing (ITS) and three irrigated late sowings (ILS) were imposed to provide terminal high temperature over the tested genotypes. The ILS was Nov $25\left(\mathrm{D}_{1}\right)$ three ILS of were Dec $10\left(\mathrm{D}_{2}\right)$, Dec 25 and Jan $10\left(\mathrm{D}_{4}\right)$, respectively. Sowing times were accommodated in main-plot and the test genotypes were assigned to sub-plot. The unit plot size was $4 \mathrm{~m} \times 5 \mathrm{~m}$. Temperature $\left({ }^{0} \mathrm{C}\right)$ imposed $(10$-day's average of minimum, maximum and its mean) during sowing to physiological maturity of wheat genotypes sowing in different times (D) at is presented in Appendix-1 and average temperature imposed on growth stages of wheat genotypes (V) by sowing times (D) is presented in Appendix 2. After well preparation of land, seeds @ $120 \mathrm{~kg} \mathrm{ha}^{-1}$ of each variety / lines were sown continuously in lines $20 \mathrm{~cm}$ apart. Each of the plots was fertilized @ 120-27-50-20-1-5000 kg $\mathrm{ha}^{-1} \mathrm{~N}-\mathrm{P}-\mathrm{K}-\mathrm{S}-\mathrm{B}-\mathrm{CD}$. Cowdung was applied during land preparation. The source of N, P, K, S and $\mathrm{B}$ were urea, TSP, MOP, gypsum and boric acid, respectively. All of TSP, MOP, gypsum and boric acid; and two-third of urea were used as basal during final land preparation. Rest urea was applied as top-dress at CRI stage followed by irrigation. Three irrigations were provided (one at CRI stage, one early booting stage and one at initiation in grain filling). The plot was kept weed free up to 30 days. No plant protection measures taken to control insects and diseases. Each of genotypes was harvested after its maturity. Data on days to booting, heading, anthesis, physiological maturity, yield and yield contributing characters were recorded and the grain yield was adjusted at $12 \%$ moisture level. Recorded data were analyzed statistically and the means were tested by the LSD at $5 \%$ level. 
Effect of Terminal High Temperature Imposed by Late Sowing on Phenological Traits of Wheat

\section{Results and Discussion}

The results of studied characters have been presented in the tables 1 to 9 . Findings of each character are discussed below:

\section{Booting stage}

In irrigated timely sowings (ITS) all the genotypes phased their booting stage between 63-68 days. After timely sowing i.e. in late, the days of all genotypes decreased gradually. In late sowing conditions increased temperature (Appendix 2) resulted in less time to attain booting stage. Similar result was also observed by Nahar, K. et al. (2010). Among the variety, BARI Gom 28 looks significantly less time. In late sowing conditions, took average 5.0 -13.3\% fewer days than timely sowing. BARI Gom 28, BARI Gom 27 and BAW 1051 required 4.8-11.1\%, 3.0-7.6\% and $4.6-9.2 \%$ less days respectively than timely sowing. That is, the new varieties needed fewer days to attain booting stage as compared to BARI Gom 26. It indicated that, the BARI Gom 28 and BARI Gom 27 possess more heat tolerance.

Table 1. Effect of terminal high temperature on days to booting of wheat genotypes (V) imposed by late sowing times (D) during 2012-13 and 2013-14

\begin{tabular}{|c|c|c|c|c|c|c|c|c|c|c|}
\hline \multirow{3}{*}{ V } & \multicolumn{5}{|c|}{$2012-13$} & \multicolumn{5}{|c|}{ 2013-14 } \\
\hline & $\mathrm{D}_{1}$ & $\mathrm{D}_{2}$ & $\mathrm{D}_{3}$ & $\mathrm{D}_{4}$ & \multirow{2}{*}{$\begin{array}{c}\text { Mean- } \\
\text { V }\end{array}$} & $\mathrm{D}_{1}$ & $\mathrm{D}_{2}$ & $\mathrm{D}_{3}$ & $\mathrm{D}_{4}$ & \multirow{2}{*}{$\begin{array}{c}\text { Mean- } \\
\mathrm{V}\end{array}$} \\
\hline & ITS & \multicolumn{3}{|c|}{ ILS } & & ITS & \multicolumn{3}{|c|}{ ILS } & \\
\hline $\mathrm{V}_{1}$ & 64 & $\begin{array}{c}63 \\
(1.56)\end{array}$ & $\begin{array}{c}62 \\
(3.12)\end{array}$ & $\begin{array}{c}55 \\
(14.1)\end{array}$ & 61 & 66 & $\begin{array}{c}64 \\
(1.72)\end{array}$ & $\begin{array}{c}60 \\
(4.23)\end{array}$ & $\begin{array}{c}52 \\
(13.8)\end{array}$ & 60 \\
\hline $\mathrm{V}_{2}$ & 63 & $\begin{array}{c}62 \\
(1.58)\end{array}$ & $\begin{array}{c}60 \\
(4.76)\end{array}$ & $\begin{array}{c}54 \\
(14.2)\end{array}$ & 59.7 & 64 & $\begin{array}{c}62 \\
(1.77)\end{array}$ & $\begin{array}{c}59 \\
(5.22)\end{array}$ & $\begin{array}{c}51 \\
(15.2)\end{array}$ & 59 \\
\hline $\mathrm{V}_{3}$ & 67 & $\begin{array}{c}65 \\
(2.98)\end{array}$ & $\begin{array}{c}63 \\
(5.97)\end{array}$ & $\begin{array}{c}57 \\
(14.9)\end{array}$ & 63 & 68 & $\begin{array}{c}65 \\
(3.21)\end{array}$ & $\begin{array}{c}61 \\
(6.14)\end{array}$ & $\begin{array}{c}55 \\
(16.7)\end{array}$ & 62.3 \\
\hline $\mathrm{V}_{4}$ & 64 & $\begin{array}{c}63 \\
(1.56)\end{array}$ & $\begin{array}{c}60 \\
(6.25)\end{array}$ & $\begin{array}{c}56 \\
(12.5)\end{array}$ & 60.7 & 65 & $\begin{array}{c}62 \\
(1.68)\end{array}$ & $\begin{array}{c}58 \\
(5.98)\end{array}$ & $\begin{array}{c}51 \\
(13.8)\end{array}$ & 59 \\
\hline Mean-D & 64.5 & $\begin{array}{c}63.2 \\
(2.01)\end{array}$ & $\begin{array}{c}61.2 \\
(5.11)\end{array}$ & $\begin{array}{c}55.5 \\
(13.9)\end{array}$ & - & 65.7 & $\begin{array}{c}63.2 \\
(2.09)\end{array}$ & $\begin{array}{c}59.5 \\
(5.39)\end{array}$ & $\begin{array}{c}52.2 \\
(14.8)\end{array}$ & - \\
\hline
\end{tabular}

\begin{tabular}{l|c|c|c|c|c|c|c|c|c|c|c|c}
\hline \multirow{2}{*}{ Year } & \multicolumn{4}{|c|}{ LS } & \multicolumn{4}{c|}{ LSD $_{(0.05)}$} & \multicolumn{4}{c}{ CV (\%) } \\
\cline { 2 - 13 } & $\mathrm{D}$ & $\mathrm{V}$ & $\mathrm{DxV}^{\mathrm{l}}$ & $\mathrm{DxV}$ & $\mathrm{D}$ & $\mathrm{V}$ & $\mathrm{DxV}$ & $\mathrm{DxV}$ & $\mathrm{D}$ & $\mathrm{V}$ & $\mathrm{DxV}$ & $\mathrm{DxV}^{\mathrm{c}}$ \\
\hline $2012-13$ & $* * *$ & $* *$ & $* *$ & $* *$ & 4.14 & 2.52 & 2.47 & 2.47 & 2.30 & 2.30 & 2.30 & 2.30 \\
$2013-14$ & $* *$ & $* *$ & $* *$ & $* *$ & 1.17 & 1.06 & 2.12 & 2.12 & 2.10 & 2.24 & .2 .24 & 2.24 \\
\hline
\end{tabular}

Figure in the parenthesis indicates decrease day in \% over ITS

\section{Heading stage}

Like booting stage, high temperature imposed by sowing times influenced on heading of all the genotypes at both the years. In ITS all the genotypes phased their heading stage between 6772 days (Table 2). After ITS, days to heading of all genotypes were decreased gradually. This is might be due to higher temperature prevailed in ILS (Table 2). Nahar, K. et al. (2010) also observed the similar result. Among the genotypes, BARI Gom 28 took significantly less time in all sowing times. New wheat varieties, BARI Gom 28, BARI Gom 27, BARI Gom 26 and BAW 1051 required $1.9-10.8 \%, 2.4-9.3 \%$ and $0.0-8.7 \%$ less days respectively than timely sowing. These results implied that the performance in respect of heat tolerance of advanced genotypes were as in order of BARI Gom 28 > BARI Gom 27 > BAW 1051>BARI Gom 26 
Hossain et al.

Table 2. Effect of terminal high temperature on days to heading of wheat genotypes (V) imposed by late sowing times (D) during 2012-13 and 2013-14

\begin{tabular}{|c|c|c|c|c|c|c|c|c|c|c|}
\hline \multirow{3}{*}{$\mathrm{V}$} & \multicolumn{5}{|c|}{$2012-13$} & \multicolumn{5}{|c|}{$2013-14$} \\
\hline & $\mathrm{D}_{1}$ & $\mathrm{D}_{2}$ & $\mathrm{D}_{3}$ & $\mathrm{D}_{4}$ & \multirow{2}{*}{$\begin{array}{c}\text { Mean- } \\
\mathrm{V}\end{array}$} & $\mathrm{D}_{1}$ & $\mathrm{D}_{2}$ & $\mathrm{D}_{3}$ & $\mathrm{D}_{4}$ & Mean- \\
\hline & ITS & \multicolumn{3}{|c|}{ ILS } & & ITS & \multicolumn{3}{|c|}{ ILS } & V \\
\hline $\mathrm{V}_{1}$ & 71 & $\begin{array}{c}70 \\
(1.40)\end{array}$ & $\begin{array}{c}65 \\
(8.45)\end{array}$ & $\begin{array}{c}60 \\
(15.4)\end{array}$ & 66.5 & 72 & $\begin{array}{c}699 \\
(1.68)\end{array}$ & $\begin{array}{c}64 \\
(7.84)\end{array}$ & $\begin{array}{c}58 \\
(14.8)\end{array}$ & 65.7 \\
\hline $\mathrm{V}_{2}$ & 71 & $\begin{array}{c}70 \\
(1.40)\end{array}$ & $\begin{array}{c}64 \\
(9.85)\end{array}$ & $\begin{array}{c}58 \\
(18.30)\end{array}$ & 65.7 & 70 & $\begin{array}{c}68 \\
(1.65)\end{array}$ & $\begin{array}{c}63 \\
(8.52)\end{array}$ & $\begin{array}{c}57 \\
(16.2)\end{array}$ & 64.5 \\
\hline $\mathrm{V}_{3}$ & 74 & $\begin{array}{c}72 \\
(2.77)\end{array}$ & $\begin{array}{c}66 \\
(10.81)\end{array}$ & $\begin{array}{c}62 \\
(16.2)\end{array}$ & 68.5 & 75 & $\begin{array}{c}73 \\
(3.10)\end{array}$ & $\begin{array}{c}65 \\
(9.97)\end{array}$ & $\begin{array}{c}60 \\
(14.8)\end{array}$ & 68.2 \\
\hline $\mathrm{V}_{4}$ & 71 & $\begin{array}{c}69 \\
(2.81)\end{array}$ & $\begin{array}{c}64 \\
(9.85)\end{array}$ & $\begin{array}{c}59 \\
(16.9)\end{array}$ & 65.7 & 70 & $\begin{array}{c}68 \\
(2.97)\end{array}$ & $\begin{array}{c}63 \\
(8.87)\end{array}$ & $\begin{array}{c}57 \\
(15.2)\end{array}$ & 64.5 \\
\hline Mean-D & 71.7 & 70.2 & 64.5 & 59.7 & - & 71.3 & 69.5 & 63.7 & 58 & - \\
\hline \multirow[t]{2}{*}{ Year } & \multicolumn{5}{|c|}{$\operatorname{LSD}_{(0.05)}$} & \multicolumn{5}{|c|}{$\mathrm{CV}(\%)$} \\
\hline & & D & \begin{tabular}{l|l}
$\mathrm{V}$ &
\end{tabular} & $\mathrm{D} \times \mathrm{V}^{\mathrm{l}}$ & $\mathrm{VxV}^{\mathrm{c}}$ & D & V & & $\overline{\mathrm{DxV}} \mathrm{l}^{\mathrm{l}}$ & $\mathrm{DxV}^{\mathrm{c}}$ \\
\hline $2012-13$ & & 13 & 2.12 & 2.09 & 1.77 & 1.77 & 1.77 & & 1.77 & 1.77 \\
\hline 2013-14 & & 74 & 1.37 & 2.75 & 2.75 & 2.65 & $2.4 \varepsilon$ & & 2.48 & 2.48 \\
\hline
\end{tabular}

Figure in the parenthesis indicates decrease day in \% over ITS

\section{Anthesis}

Under high temperature conditions, earlier heading is advantageous in the retention of more green leaves at anthesis, leading to a smaller reduction in yield. Growth chamber and greenhouse studies suggest that high temperature is most deleterious when flowers are first visible and sensitivity continues for 10-15 days. Among the reproductive phases fertilization (13 days after anthesis) is one of the most sensitive stages to high temperature in various plants. In the present experiment, terminal high temperature imposed by sowing times had significant influence on days to anthesis of tested wheat genotypes. There was also significant variation among the genotypes to attain anthesis. Of the tested genotypes BARI Gom 28 took less time (74 days) to reach the anthesis stage as compared to other genotypes in irrigated timely sowing (ITS). After ITS, days required to anthesis of all the genotypes decreased gradually. In irrigated late sowing (ILS) conditions, BARI Gom 28 required the shortest duration and other two advanced genotypes needed longer duration in each location to reach the anthesis stage. In the high temperature stress condition, the days to anthesis reduced by $6.7-14.7 \%$ in BARI Gom 28, 1.3-10.7 \% in BARI Gom 27 and 2.7-9.5\% in BAW 1051. Ubaidullah et al. (2006) reported the same findings and observed that generally late sowing imposed negative effects on all the traits except BARI Gom 28. These results implied that in case anthesis the performance in respect of heat tolerance of tested genotypes were as in order of BARI Gom 28> BARI Gom 27 > BAW 1051>BARI Gom 26 
Effect of Terminal High Temperature Imposed by Late Sowing on Phenological Traits of Wheat

Table 3. Effect of terminal high temperature on days to anthesis of wheat genotypes (V) imposed by late sowing times (D) during 2012-13 and 2013-14

\begin{tabular}{|c|c|c|c|c|c|c|c|c|c|c|}
\hline \multirow{3}{*}{ V } & \multicolumn{5}{|c|}{$2012-13$} & \multicolumn{5}{|c|}{ 2013-14 } \\
\hline & $D_{1}$ & $\mathrm{D}_{2}$ & $\mathrm{D}_{3}$ & $\mathrm{D}_{4}$ & \multirow{2}{*}{$\begin{array}{c}\text { Mean- } \\
\mathrm{V}\end{array}$} & $\mathrm{D}_{1}$ & $\mathrm{D}_{2}$ & $\mathrm{D}_{3}$ & $\mathrm{D}_{4}$ & \multirow{2}{*}{$\begin{array}{c}\text { Mean- } \\
\text { V }\end{array}$} \\
\hline & ITS & \multicolumn{3}{|c|}{ ILS } & & ITS & \multicolumn{3}{|c|}{ ILS } & \\
\hline $\mathrm{V}_{1}$ & 79 & $\begin{array}{c}78 \\
(1.26)\end{array}$ & $\begin{array}{c}75 \\
(5.06)\end{array}$ & $\begin{array}{c}72 \\
(8.86)\end{array}$ & 76 & 77 & $\begin{array}{c}76 \\
(1.67)\end{array}$ & $\begin{array}{c}74 \\
(6.63)\end{array}$ & $\begin{array}{c}70 \\
(10.8)\end{array}$ & 74.2 \\
\hline $\mathrm{V}_{2}$ & 75 & $\begin{array}{c}74 \\
(1.33)\end{array}$ & $\begin{array}{c}67 \\
(10.67)\end{array}$ & $\begin{array}{c}64 \\
(14.67)\end{array}$ & 70 & 76 & $\begin{array}{c}75 \\
(1.59)\end{array}$ & $\begin{array}{c}68 \\
(11.4)\end{array}$ & $\begin{array}{c}63 \\
(15.2)\end{array}$ & 70.5 \\
\hline$V_{3}$ & 78 & $\begin{array}{c}77 \\
(1.28)\end{array}$ & $\begin{array}{c}67 \\
(14.10)\end{array}$ & $\begin{array}{c}64 \\
(17.9)\end{array}$ & 71.5 & 79 & $\begin{array}{c}77 \\
(1.32)\end{array}$ & $\begin{array}{c}67 \\
(14.2)\end{array}$ & $\begin{array}{c}64 \\
(18.5)\end{array}$ & 71.7 \\
\hline $\mathrm{V}_{4}$ & 74 & $\begin{array}{c}75 \\
(1.31)\end{array}$ & $\begin{array}{c}66 \\
(13.10)\end{array}$ & $\begin{array}{c}64 \\
(15.78)\end{array}$ & 70.2 & 74 & $\begin{array}{c}75 \\
(1.62)\end{array}$ & $\begin{array}{c}66 \\
(13.8)\end{array}$ & $\begin{array}{c}63 \\
(16.2)\end{array}$ & 69.5 \\
\hline $\begin{array}{c}\text { Mean- } \\
\text { D }\end{array}$ & 77.7 & $\begin{array}{c}75.2 \\
(3.21)\end{array}$ & $\begin{array}{c}68.7 \\
(11.58)\end{array}$ & $\begin{array}{c}63.5 \\
(18.27)\end{array}$ & - & 77.2 & $\begin{array}{c}75.7 \\
(1.55)\end{array}$ & $\begin{array}{c}69 \\
(11.5)\end{array}$ & $\begin{array}{c}65 \\
(15.1)\end{array}$ & - \\
\hline
\end{tabular}

\begin{tabular}{l|c|c|c|c|c|c|c|c}
\hline \multirow{2}{*}{ Year } & \multicolumn{9}{|c|}{ LSD $_{(0.05)}$} & $\mathrm{CV}(\%)$ & & \\
& $\mathrm{D}$ & $\mathrm{V}$ & $\mathrm{D} \times \mathrm{V}^{\mathrm{y}}$ & $\mathrm{D} \times \mathrm{V}^{\mathrm{y}}$ & $\mathrm{D}$ & $\mathrm{V}$ & $\mathrm{D} \times \mathrm{Vl}$ & $\mathrm{DxV}$ \\
\hline $2012-13$ & 5.13 & 2.12 & 2.09 & 2.09 & 1.77 & 1.77 & 1.77 & 1.77 \\
$2013-14$ & 1.74 & 1.37 & 2.75 & 2.75 & 2.65 & 2.48 & 2.48 & 2.48 \\
\hline
\end{tabular}

Figure in the parenthesis indicates decrease day in $\%$ over ITS

\section{Physiological maturity}

It is generally known that the duration of maturity of any crop is reduced by stress condition. High temperature in the post anthesis period shortens the duration of grain-filling (Wiegand and Cuellar, 1981). In our study, terminal high temperature imposed by sowing times had also considerable influence on days to physiological maturity of tested wheat genotypes. There was also significant variation among the genotypes to attain maturity. In irrigated timely sowing conditions (ITS), BARI Gom 27 took significantly the highest time for physiological maturation (108 days) and which was followed by \& BAW 1051 (106 days) while it was the lowest in BARI Gom 28. BARI Gom 28 also took the lowest days (106 days) among other two advanced genotypes (105 days) for maturation (Table 4). After ITS, days required to maturity of all the genotypes decreased gradually. In irrigated late sowing (ILS) conditions, BARI Gom 28 required the shortest duration and other two advanced genotypes needed longer duration to attain physiological maturity. In this experiment, in respect of sowing times and genotypes the temperature during the physiological maturing period was $24.4-25.8 \mathrm{C}$ in case of ITS, and it was 23.3-29.2 C in ILS conditions. In late sowings, temperatures prevailed higher during physiological maturity stage of wheat than ITS. In this condition, the days to maturity reduced by $0.9-12.6 \%$ in BARI Gom 28, 1.0-9.5 \% in BARI Gom 27 and 1.9-12.4\% in BAW 1051. That is why, due to higher temperature all the tested genotypes matured earlier in ILS condition as compared to ITS. There is a similarity between the result of the present study and that of Ubaidullah et al. (2006) and Nahar et al. (2010). These results implied that in case maturity the performance in respect of heat tolerance of tested genotypes were as in order of BARI Gom 28> BAW 1051 > BARI Gom 26> BARI Gom 27. 
Hossain et al.

Table 4. Effect of terminal high temperature on days to physiological maturity of wheat genotypes (V) imposed by late sowing times (D) during 2012-13 and 2013-14

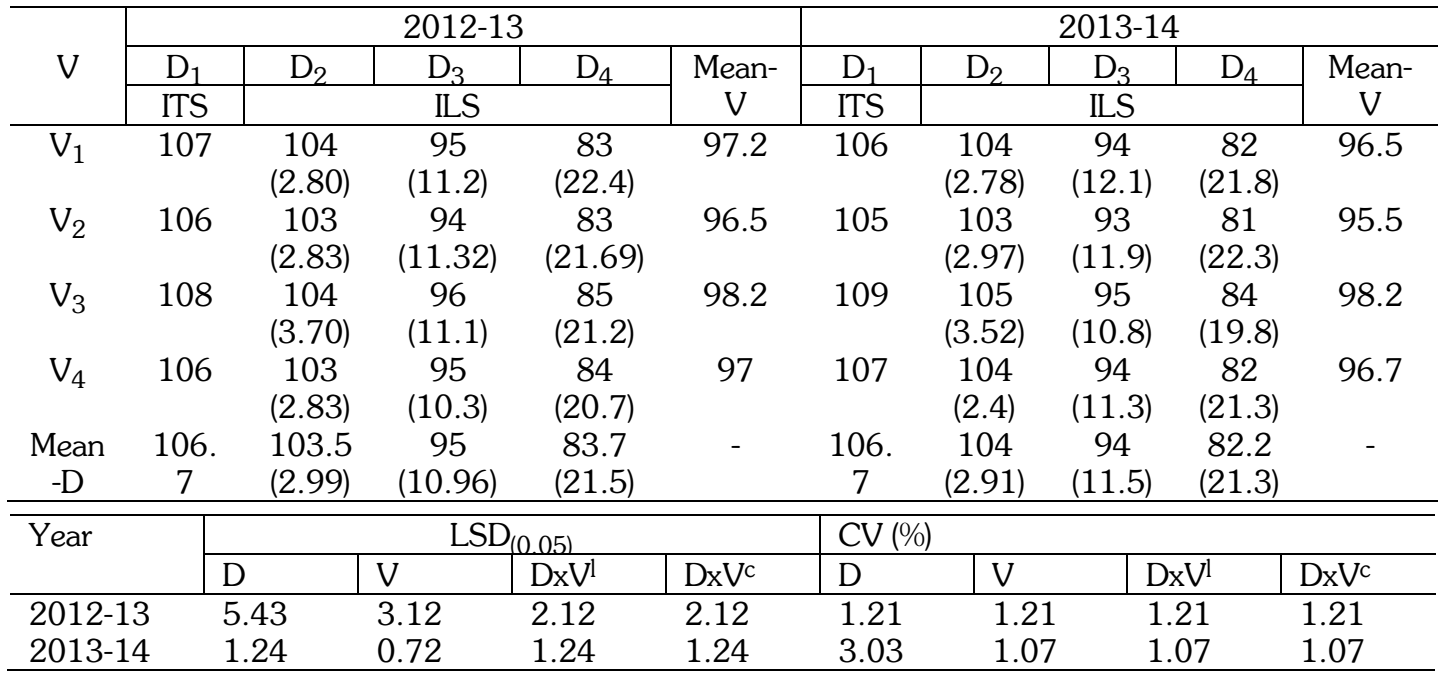

\section{Plant height}

Effect of terminal high temperature imposed by sowing times on plant height at maturity was statistically significantamong the tested genotypes and also interaction effect between sowing times and genotypes (Table 5). BAW 1120 and BAW 1051 produced numerically the taller plants $(99 \mathrm{~cm})$ while BARI Gom 28 produced the shortest plant $(93.7 \mathrm{~cm})$ in ITS condition. In ILS conditions, maximum plant height $(94.5 \mathrm{~cm})$ was recorded from BARI Gom 27 followed by BARI Gom $28(94.3 \mathrm{~cm})$ and BAW $1051(91.8 \mathrm{~cm})$ sowing on Dec 10. In case of Dec 25 sowing, BAW 1051 and BARI Gom 27 produced the plant of same height $(93.5 \mathrm{~cm})$ and BARI Gom 28 gave the shortest plant $(92.5 \mathrm{~cm})$. In the late sowing on Jan 10, BAW 1051 gave the maximum plant $(94.8 \mathrm{~cm})$ followed by BARI Gom $27(93 \mathrm{~cm})$ while BARI Gom 28 resulted shortest plant height $(92.7 \mathrm{~cm})$. These results implied that performance of advanced genotypes in respect of taller plant height was in order of BARI Gom 26 BARI Gom 27> BARI Gom 28>BAW 1051.

Table 5. Effect of terminal high temperature on plant height $(\mathrm{cm})$ of wheat genotypes (V) imposed by late sowing times (D) during 2012-13 and 2013-14

\begin{tabular}{|c|c|c|c|c|c|c|c|c|c|c|}
\hline \multirow{3}{*}{ V } & \multicolumn{5}{|c|}{$2012-13$} & \multicolumn{5}{|c|}{$2013-14$} \\
\hline & \multirow{2}{*}{$\begin{array}{l}\mathrm{D}_{1} \\
\text { ITS }\end{array}$} & $\mathrm{D}_{2}$ & $\mathrm{D}_{3}$ & \multirow[t]{2}{*}{$\mathrm{D}_{4}$} & \multirow{2}{*}{$\begin{array}{c}\text { Mean- } \\
\text { V }\end{array}$} & \multirow{2}{*}{$\frac{\mathrm{D}_{1}}{\mathrm{ITS}}$} & $\mathrm{D}_{2}$ & $\mathrm{D}_{3}$ & \multirow[t]{2}{*}{$\mathrm{D}_{4}$} & \multirow{2}{*}{$\begin{array}{c}\text { Mean- } \\
\text { V }\end{array}$} \\
\hline & & \multicolumn{2}{|r|}{ ILS } & & & & \multirow[b]{2}{*}{106.4} & ILS & & \\
\hline $\mathrm{V}_{1}$ & 109.8 & 102.7 & 96.2 & 82.2 & 97.7 & 110.1 & & 95.8 & 83.2 & 98.8 \\
\hline $\mathrm{V}_{2}$ & 103.7 & 97.8 & 96.4 & 81.4 & 94.8 & 105.4 & 102.3 & 95.4 & 82.3 & 96.3 \\
\hline $\mathrm{V}_{3}$ & 103.1 & 102.2 & 97.2 & 79.2 & 95.5 & 105.2 & 103.4 & 96.7 & 80.5 & 96.1 \\
\hline $\mathrm{V}_{4}$ & 103.1 & 100.4 & 98.5 & 81.1 & 95.8 & 104.8 & 102.3 & 99.7 & 81.7 & 97.1 \\
\hline $\begin{array}{c}\text { Mean- } \\
\text { D }\end{array}$ & 104.9 & 100.7 & 97.1 & 80.9 & - & 106.3 & 103.6 & 96.9 & 81.9 & - \\
\hline \multirow[t]{2}{*}{ Year } & & \multicolumn{4}{|c|}{$\mathrm{LSD}_{(0.05)}$} & \multicolumn{5}{|c|}{$\mathrm{CV}(\%)$} \\
\hline & & $\mathrm{D}$ & $\mathrm{V}$ & $\mathrm{DxV}^{\mathrm{l}}$ & $\mathrm{DxV}^{\mathrm{c}}$ & $\mathrm{D}$ & & $J$ & $\mathrm{DxV}^{\mathrm{l}}$ & $\mathrm{DxV}^{\mathrm{c}}$ \\
\hline $2012-$ & & 7.79 & 1.79 & 4.60 & 4.60 & 2.8 & & & 2.82 & 2.82 \\
\hline 2013- & & 3.03 & 2.62 & 2.49 & 2.49 & 1.7 & & 54 & 1.54 & 1.54 \\
\hline
\end{tabular}

Figure in the parenthesis indicates decrease day in $\%$ over ITS 
Effect of Terminal High Temperature Imposed by Late Sowing on Phenological Traits of Wheat

\section{Spike density}

Spike density is one the important yield contributing factor for wheat. It may be varied due to different stress situation. In this study, both the main effect of terminal high temperature forced by sowing times and genotypes was significant on spike density in each location. Interaction effect between sowing time and genotypes was significant. Spike density decreased with the delay in sowings (Table 6). The genotype BARI Gom 28 produced second highest number (380) of spike $\mathrm{m}^{-2}$ and the value was statistically identical to the value (351) noted from BAW 1051. In the latest sowing of Jan 10, the advanced genotypes produced higher spikes per unit area than the released variety, BARI Gom 26. That is, among the advanced genotypes, BARI Gom 27 and BARI Gom 28 performed better both in ITS and ILS condition. On the other hand, the same two genotypes performed better in ILS condition.

Table 6. Effect of terminal high temperature on spike density (Number $\mathrm{m}^{-2}$ ) of wheat genotypes (V) imposed by late sowing times (D) during 2012-13 and 2013-14

\begin{tabular}{|c|c|c|c|c|c|c|c|c|c|c|}
\hline \multirow{3}{*}{ V } & \multicolumn{5}{|c|}{$2012-13$} & \multicolumn{5}{|c|}{$2013-14$} \\
\hline & $\mathrm{D}_{1}$ & $\mathrm{D}_{2}$ & $\mathrm{D}_{3}$ & $\mathrm{D}_{4}$ & \multirow{2}{*}{$\begin{array}{c}\text { Mean- } \\
\text { V }\end{array}$} & $\mathrm{D}_{1}$ & $\mathrm{D}_{2}$ & $\mathrm{D}_{3}$ & $\mathrm{D}_{4}$ & \multirow[t]{2}{*}{ Mean- V } \\
\hline & ITS & \multicolumn{3}{|c|}{ ILS } & & ITS & \multicolumn{3}{|c|}{ ILS } & \\
\hline $\mathrm{V}_{1}$ & 388 & 341 & 319 & 299 & 336.7 & 362 & 324 & 314 & 311 & 327.7 \\
\hline $\mathrm{V}_{2}$ & 372 & 349 & 319 & 306 & 336.5 & 342 & 329 & 322 & 317 & 327.5 \\
\hline $\mathrm{V}_{3}$ & 458 & 423 & 348 & 299 & 382 & 412 & 419 & 398 & 402 & 407.7 \\
\hline $\mathrm{V}_{4}$ & 456 & 348 & 315 & 306 & 356.2 & 398 & 351 & 319 & 302 & 342.5 \\
\hline Mean-D & 418.5 & 365.2 & 325.2 & 302.5 & - & 389.7 & 355.7 & 338.2 & 333 & - \\
\hline
\end{tabular}

\begin{tabular}{l|c|c|c|c|c|c|c|c}
\hline \multirow{2}{*}{ Year } & \multicolumn{4}{|c|}{ LSD $_{(0.05)}$} & \multicolumn{4}{c}{$\mathrm{CV}(\%)$} \\
\cline { 2 - 9 } & $\mathrm{D}$ & $\mathrm{V}$ & $\mathrm{D} \times \mathrm{V}^{\mathrm{l}}$ & $\mathrm{D} \times \mathrm{V}^{\mathrm{c}}$ & $\mathrm{D}$ & $\mathrm{V}$ & $\mathrm{DxV}^{\mathrm{l}}$ & $\mathrm{DxV}^{\mathrm{c}}$ \\
\hline $2012-13$ & 21.45 & 21.45 & 11.42 & 11.42 & 7.04 & 9.96 & 11.65 & 11.65 \\
$2013-14$ & 27.10 & 15.40 & 51.25 & 50.71 & 8.69 & 8.69 & 8.39 & 8.39 \\
\hline
\end{tabular}

Figure in the parenthesis indicates decrease day in \% over ITS

\section{Grains spike-1}

Number of grains spike $e^{-1}$ is also one of the major criteria to influence grain yield of wheat. Heat stress, singly or in combination with drought, it is common constraint during anthesis and grain filling stages in many cereal crops of temperate region (Nahar et al., 2010). In this study, terminal high temperature imposed by late sowings had significant effect on number of grains spike $^{-1}$ (Table 7). On the other hand, interaction effect between sowing times and genotypes was significant. The significant interaction effect between sowing times and genotypes indicated that tested genotypes performed differently in different sowing times. Here, BAW 1051 produced numerically the maximum number of grains (48.3) spike ${ }^{-1}$ from the late sowing of Dec 10. Statistically identical numbers of grain spike ${ }^{-1}$ were also recorded from timely sowing of Nov 30 and late sowings of Dec 25 and January 10. This implied that, this genotype could be sown in timely sowing time and even very late i.e. up to Jan 1 for getting higher number of grain spike $e^{-1}$. High temperature prevailed in reproductive stage due to late sowing could not affect grain formation indicating that this genotype could be identified as a good heat tolerant genotype, if data is authentic. Next minimum numbers of grain (48.0) spike ${ }^{-1}$ was recorded from BARI Gom 28 in late sowing of Dec 10 and it was identical to the number noted from the delayed sowing of Jan 10. On the contrary, late sowing Dec 25 and timely sowing Nov 25 of the same genotype produced e significantly minimum numbers of grains. During reproductive stage, the mean temperature was higher (in late sowing conditions $\left(20.9-29.0{ }^{0} \mathrm{C}\right.$ for Dec 10 sowing, 22.5-29.4 ${ }^{\circ} \mathrm{C}$ for Dec 25 sowing and 24.0-28.0 ${ }^{\circ} \mathrm{C}$ for Jan sowing) than timely 
Hossain et al.

sowing $\left(17.0-25.7^{0} \mathrm{C}\right)$. The data on temperature and result in respect of grain spike ${ }^{-1}$ might be inconsistent.

Table 7. Effect of terminal high temperature on grains spike ${ }^{-1}$ of wheat genotypes $(\mathrm{V})$ imposed by late sowing times (D) during 2012-13 and 2013-14

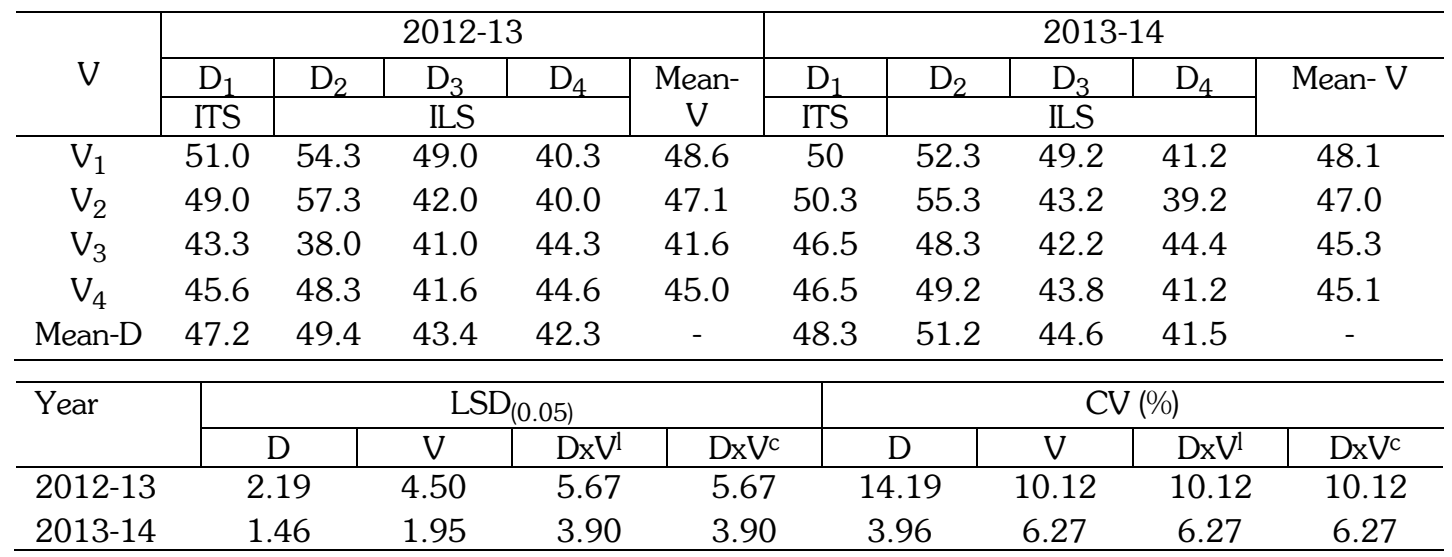

Figure in the parenthesis indicates decrease day in \% over ITS

\section{Thousand grain weight (TGW)}

Like number of grains spike $e^{-1}$ TGW was also influenced by the terminal high temperature imposed sowing times (averaged over genotypes) and genotypes (averaged over sowing times. Interaction effect between genotypes and sowing times was significant (Table 8). TGW averaged over genotypes also decreased with delay in sowing. The maximum TGW of $48.4 \mathrm{~g}$ was recorded from irrigated timely sowing (Nov 30) and it was statistically identical to the weight noted from late sowings of Dec 15-30. Last sowing (Jan 15) resulted in the minimum TGW (23.3 g). Here, BARI Gom 28 succeeded to generate significantly the maximum TGW. Other genotypes performed similarly. This result implied that, all the tested genotypes were found to be better for normal and late sowings up to Dec 30. All the genotypes also resulted in lower TGW in late sowings of Dec 25 and Jan 10. On the contrary, higher TGW was noted from Nov 25 and Dec 10 sowings.

Table 8. Effect of terminal high temperature on TGW (g) of wheat genotypes (V) imposed by late sowing times (D) at Rajshahi during 2012-13 and 2013-14

\begin{tabular}{|c|c|c|c|c|c|c|c|c|c|c|}
\hline \multirow{3}{*}{ V } & \multicolumn{5}{|c|}{$2012-13$} & \multicolumn{5}{|c|}{$2013-14$} \\
\hline & $\mathrm{D}_{1}$ & $\mathrm{D}_{2}$ & $\mathrm{D}_{3}$ & $\mathrm{D}_{4}$ & \multirow{2}{*}{$\begin{array}{c}\text { Mean- } \\
\text { V }\end{array}$} & $\mathrm{D}_{1}$ & $\mathrm{D}_{2}$ & $\mathrm{D}_{3}$ & $\mathrm{D}_{4}$ & \multirow{2}{*}{$\begin{array}{c}\text { Mean } \\
\text { V }\end{array}$} \\
\hline & ITS & \multicolumn{3}{|c|}{ ILS } & & ITS & \multicolumn{3}{|c|}{ ILS } & \\
\hline $\mathrm{V}_{1}$ & 44.6 & 36.6 & 32.0 & 29.3 & 35.6 & 45.3 & 44.8 & 33.8 & 30.4 & 38.5 \\
\hline $\mathrm{V}_{2}$ & 43.0 & 37.0 & 34.3 & 34.0 & 39.5 & 44.7 & 43.5 & 34.2 & 32.4 & 38.7 \\
\hline$v_{3}$ & 35.0 & 30.6 & 23.3 & 23.3 & 28.1 & 38.5 & 37.9 & 29.5 & 24.3 & 32.5 \\
\hline $\mathrm{V}_{4}$ & 49.0 & 39.3 & 34.0 & 35.0 & 39.3 & 48.7 & 45.5 & 35.2 & 33.4 & 40.7 \\
\hline Mean-D & 45.2 & 42.2 & 32.8 & 30.4 & - & 44.3 & 42.9 & 33.1 & 30.0 & - \\
\hline \multirow[t]{2}{*}{ Year } & \multicolumn{5}{|c|}{$\operatorname{LSD}_{(0.05)}$} & \multicolumn{5}{|c|}{ CV (\%) } \\
\hline & & 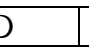 & $\mathrm{V}$ & $\mathrm{D} \times \mathrm{V}^{\mathrm{l}}$ & $\mathrm{D} \times \mathrm{Vc}^{\mathrm{c}}$ & D & & V & $\mathrm{DxVl}$ & $\mathrm{DxV}$ \\
\hline $2012-13$ & & 45 & 3.04 & 8.81 & 8.81 & 10. & & 14.19 & 14.19 & 14.19 \\
\hline 2013-14 & & 04 & 2.48 & 4.96 & 4.96 & 4.9 & & 7.15 & 7.15 & 7.15 \\
\hline
\end{tabular}

Figure in the parenthesis indicates decrease day in \% over ITS 
Effect of Terminal High Temperature Imposed by Late Sowing on Phenological Traits of Wheat

\section{Grain Yield}

Interaction between of terminal high temperature imposed by sowing times and genotypes wheat had significant effect on grain yield (Table 9). This meant that grain yield of each genotype was different in each sowing times.

In irrigated timely sowing conditions (ITS), all the genotypes resulted in significantly higher grain yield and thereafter yield decreased with the delay of sowing times. That is, yield recorded from ITS was significantly higher than all sowings of ILS conditions. Under ILS conditions, the advanced genotype BAW 1141 generated significantly the highest grain yield $\left(5.31 \mathrm{t} \mathrm{ha}{ }^{-1}\right)$. This yield was statistically identical to the yield noted from other advanced genotypes. Just after 15days of ITS, (Dec 10) there was no significant yield variation among the genotypes but after 15 days (Dec 25) significant yield variation among the genotypes. In this sowing, yield reduction of the genotypes BARI Gom 26, BAW 1051, BARI Gom 27 and BARI Gom 28 was 26.3\%, $22.8 \%, 18.9 \%$ and $21.3 \%$, respectively as compared to ITS condition. In late sowing of Jan 10, BARI Gom 28 also produced significantly the highest yield (3.65 $\left.\mathrm{t} \mathrm{ha}^{-1}\right)$. Other two advanced genotypes performed identically resulting in a yield more than $2 \mathrm{t} \mathrm{ha}^{-1}$. At that time percent of yield reduction was remarkable and it was 39.8\%, 29.7\%, 26.4\% and 25.6.2\% in BARI Gom 26, BAW 1051, BARI Gom 27 and BARI Gom 28, respectively. Considering the yield performance, the variety BARI Gom 28 performed better than other genotypes in all sowing times though there was significant yield reduction over timely sowing. This line produced more than 4.18 tha $^{-1}$ grain yield up to Dec 25 sowing and it also produced 3.65 tha $^{-}$ 1 grain yield in January 10 sowing. This indicates that among the tested genotypes, it is better in heat stress condition. In late sowing conditions (Dec 25 -Jan 10), the grain yield was reduced by $12.8-38.8 \%$ in BARI Gom 26, 14.4-30.2\% in BAW 1051, 11.5-26.4\% in BARI Gom 27 and $17.4-25.6 \%$ in BARI Gom 28.

Table 9. Effect of terminal high temperature on grain yield ( $t \mathrm{ha}^{-1}$ ) of wheat genotypes (V) imposed by late sowing times (D) during 2012-13 and 2013-14

\begin{tabular}{|c|c|c|c|c|c|c|c|c|c|c|}
\hline \multirow{3}{*}{ V } & \multicolumn{5}{|c|}{$2012-13$} & \multicolumn{5}{|c|}{ 2013-14 } \\
\hline & \multirow{2}{*}{$\begin{array}{l}\mathrm{D}_{1} \\
\text { ITS }\end{array}$} & $\mathrm{D}_{2}$ & $\mathrm{D}_{3}$ & \multirow[t]{2}{*}{$\mathrm{D}_{4}$} & \multirow{2}{*}{$\begin{array}{c}\text { Mean- } \\
\text { V }\end{array}$} & \multirow{2}{*}{$\begin{array}{c}\mathrm{D}_{1} \\
\mathrm{ITS}\end{array}$} & $\mathrm{D}_{2}$ & \multirow{2}{*}{$\mathrm{D}_{3}$} & \multirow[t]{2}{*}{$\mathrm{D}_{4}$} & \multirow{2}{*}{$\begin{array}{c}\text { Mean- } \\
\mathrm{V}\end{array}$} \\
\hline & & & ILS & & & & & & & \\
\hline $\mathrm{V}_{1}$ & 5.15 & $\begin{array}{c}5.16 \\
(0.97)\end{array}$ & $\begin{array}{c}4.50 \\
(12.6)\end{array}$ & $\begin{array}{c}2.78 \\
(46.0)\end{array}$ & 4.39 & 5.23 & $\begin{array}{c}5.09 \\
(2.67)\end{array}$ & $\begin{array}{c}4.42 \\
(13.1)\end{array}$ & $\begin{array}{c}2.93 \\
(33.7)\end{array}$ & 4.41 \\
\hline$V_{2}$ & 4.75 & $\begin{array}{c}4.66 \\
(1.89)\end{array}$ & $\begin{array}{c}3.56 \\
(12.4)\end{array}$ & $\begin{array}{c}2.61 \\
(34.5)\end{array}$ & 4.24 & 4.57 & $\begin{array}{c}4.42 \\
(3.28)\end{array}$ & $\begin{array}{r}3.69 \\
(16.5)\end{array}$ & $\begin{array}{c}2.77 \\
(24.9)\end{array}$ & 3.86 \\
\hline$V_{3}$ & 4.47 & $\begin{array}{c}4.25 \\
(4.92)\end{array}$ & $\begin{array}{c}3.83 \\
(14.3)\end{array}$ & $\begin{array}{c}2.68 \\
(40.0)\end{array}$ & 3.81 & 4.41 & $\begin{array}{c}4.32 \\
(2.04)\end{array}$ & $\begin{array}{c}3.94 \\
(8.79)\end{array}$ & $\begin{array}{r}3.43 \\
(12.9)\end{array}$ & 4.02 \\
\hline $\mathrm{V}_{4}$ & 5.36 & $\begin{array}{c}5.08 \\
(5.22)\end{array}$ & $\begin{array}{r}4.25 \\
(20.7)\end{array}$ & $\begin{array}{c}3.75 \\
(30.0)\end{array}$ & 4.61 & 5.27 & $\begin{array}{c}5.04 \\
(4.36)\end{array}$ & $\begin{array}{c}4.11 \\
(18.4)\end{array}$ & $\begin{array}{c}3.57 \\
(13.8)\end{array}$ & 4.47 \\
\hline $\begin{array}{c}\text { Mean- } \\
\text { D }\end{array}$ & 4.93 & $\begin{array}{c}4.78 \\
(3.24) \\
\end{array}$ & $\begin{array}{c}4.18 \\
(15.21)\end{array}$ & $\begin{array}{c}3.15 \\
(36.10) \\
\end{array}$ & - & 4.87 & $\begin{array}{c}4.71 \\
(3.08) \\
\end{array}$ & $\begin{array}{c}4.04 \\
(14.1) \\
\end{array}$ & $\begin{array}{c}3.17 \\
(21.3)\end{array}$ & - \\
\hline Year & & & LSD & & & & & $\mathrm{CV}($ & & \\
\hline & & $\mathrm{D}$ & $\mathrm{V}$ & $\mathrm{D} \times \mathrm{V}^{\mathrm{l}}$ & $\mathrm{D} \times \mathrm{V}^{\mathrm{c}}$ & $\mathrm{D}$ & & V & $\mathrm{D} \times \mathrm{V}^{\mathrm{l}}$ & $\mathrm{DxV}$ \\
\hline $2012-1$ & & .78 & 3.03 & 0.77 & 0.77 & 9.3 & & 0.18 & 10.18 & 10.18 \\
\hline 2013-1 & & .47 & 0.14 & 0.29 & 0.29 & 10. & & .13 & 9.13 & 9.13 \\
\hline
\end{tabular}

Figure in the parenthesis indicates decrease day in $\%$ over ITS 
Hossain et al.

Table 10. Yield of wheat genotypes (V) decrease in percentage over irrigated timely sowing condition (TIS) for $1^{\circ} \mathrm{C}$ rise in average mean temperature from booting to maturity at Rajshahi during 2012-13 and 2013-14

\begin{tabular}{|c|c|c|c|c|c|c|c|c|}
\hline \multirow[t]{3}{*}{ Genotypes } & \multicolumn{4}{|c|}{$2012-13$} & \multicolumn{4}{|c|}{ 2013-14 } \\
\hline & $D_{1}$ & $\mathrm{D}_{2}$ & $\mathrm{D}_{3}$ & $\mathrm{D}_{4}$ & $D_{1}$ & $\mathrm{D}_{2}$ & $\mathrm{D}_{3}$ & $\mathrm{D}_{4}$ \\
\hline & ITS & \multicolumn{3}{|c|}{ ILS } & ITS & \multicolumn{3}{|c|}{ ILS } \\
\hline $\mathrm{V}_{1}$ & - & 1.1 & 7.3 & 14.2 & - & 1.3 & 8.2 & 16.7 \\
\hline $\mathrm{V}_{2}$ & - & 1.7 & 8.3 & 12.5 & - & 2.1 & 10.5 & 18.9 \\
\hline$V_{3}$ & - & 3.9 & 9.3 & 12.7 & - & 4.1 & 9.5 & 12.2 \\
\hline $\mathrm{V}_{4}$ & - & 4.8 & 9.6 & 10.6 & - & 3.5 & 9.8 & 13.4 \\
\hline
\end{tabular}

It was also observed that that grain yield was found to be reduced by about by $7.7-15.4 \%$ in BARI Gom 26, 9.4-15.7 \% in BAW 1051, 9.4-12.4\% in BARI Gom 27 and 9.7-12.0\% in BARI Gom 28 from irrigated timely sowing condition (ITS) for each $1 \mathrm{C}$ rise in average mean air temperature during booting to maturity in both the season (Table 10). On the other hand, reduction percent were less for the advanced lines and new varieties. Grain yield reduction was about (-) 1.4-2.65\% in BARI Gom 28, 0.1-6.7 \% in BARI Gom 27 and 1.7-6.0\% in BAW 1051.

\section{Conclusion}

From the above study, it can be concluded that terminal high temperature imposed by late sowing significantly changes the studied phenology of advanced genotypes and the yield. Generally due to high temperature stress the stages of life cycle reduce their duration or length. The performance of all genotypes is better in all respect in irrigated timely sowings as compared to irrigated late sowings conditions. The advanced variety BARI Gom 28 is the best performing one in heat stress condition as the deviation of phenological stages reduced by the lowest percentage and the yield is the highest among all the varieties. BARI Gom 27 could take place after BARI Gom 28 followed by BAW 1051.

\section{References}

Chio, B. H., K. Y. Park and R. K. Park. 1992. A study of cultural methods for summer buckwheat sown in spring. Korean J. Crop Sci. 37:149-154.

Fischer, R. A. 1985. Physiological limitations to producing wheat in semi-tropical and tropical environments and possible criteria. In: R. C. Villareal and A. R. Klatt (Eds.), Wheats for more tropical environments p.209-230. CIMMYT, Maxico, D. F.

Liszewski, M. 1999. Response of buckwheat to early planting depending on weather conditions. Folia-Universitatis Agriculturae Stetinensis. Agricultura 79:139-141.

Michiyama, H., A. Fukui and H. Hayashi. 1998. Differences in the progression of successive flowering between summer and autumn ecotype cultivars in common buckwheat (Fagopyrum esculentum Moench). Japan J. Crop Sci. 64:498-504.

Nahar, K., K. U. Ahamed and M. Fujita. 2010. Phenological variation and its relations with yield in several wheat (Triticunm aestivum L.) cultivars under normal and late sowing mediated heat stress condition. Not. Sci. Biol. 2(3):51-56.

Pecio, A. and B. Wielgo. 1999. Buckwheat yielding and structure of plant and canopy dependent of sowing time. Frag. Agron. 16:5-17. 
Effect of Terminal High Temperature Imposed by Late Sowing on Phenological Traits of Wheat

Wahid, A., S. Gelani, M. Ashraf and M. R. Foolad. 2007. Heat tolerance in plants: An overview. Environ. Exp. Bot. 61:199-223.

Wanjura, D. F. and D. R. Buxtor. 1972. Hypocotyle and radicle elongation of cotton as affected by soil environment. Agron. J. 64:431-435.

Wiegand, C. L. and J. A. Cuellar. 1981. Duration of grain filling and kernel weight of wheat as affected by temperature. Crop Sci. 21:95-101.

Ubaidullah, T., M. Raziuddin, S. Hafeezullah, A. Ali and W. Nassimi. 2006. Screening of Wheat (Triticum aestivium L.) Genotypes for some important traits against natural terminal heat stress. Pak. J. Biol. Sci. 9:2069-2075. 
Hossain et al.

Appendix 1.Temperature $\left({ }^{0} \mathrm{C}\right)$ imposed (10-day's average of minimum, maximum and its mean) during sowing to physiological maturity of wheat genotypes sowing in different times (D) in 2012-13 and 2013-14

2012-2013

\begin{tabular}{l|cc|c|c|c|c|c|c|c|c|c|c}
\hline \multirow{2}{*}{$\begin{array}{l}\text { 10-days } \\
\text { (\#) }\end{array}$} & \multicolumn{4}{|c|}{ Minimum } & \multicolumn{4}{c|}{ Maximum } & \multicolumn{4}{c}{ Mean } \\
\cline { 2 - 13 } & $\mathrm{D}_{1}$ & $\mathrm{D}_{2}$ & $\mathrm{D}_{3}$ & $\mathrm{D}_{4}$ & $\mathrm{D}_{1}$ & $\mathrm{D}_{2}$ & $\mathrm{D}_{3}$ & $\mathrm{D}_{4}$ & $\mathrm{D}_{1}$ & $\mathrm{D}_{2}$ & $\mathrm{D}_{3}$ & $\mathrm{D}_{4}$ \\
\hline 1 & 14.8 & 11.9 & 12.5 & 10.7 & 28.5 & 21.9 & 25.2 & 22.6 & 21.7 & 16.9 & 18.8 & 16.7 \\
2 & 15.6 & 9.2 & 13.4 & 9.9 & 24.7 & 20.5 & 23.2 & 23.7 & 20.2 & 14.8 & 18.3 & 16.8 \\
3 & 9.2 & 12.9 & 10.0 & 10.2 & 20.3 & 25.3 & 22.7 & 26.7 & 14.7 & 19.0 & 16.4 & 18.5 \\
4 & 12.5 & 12.8 & 9.1 & 12.8 & 25.2 & 22.9 & 24.9 & 27.2 & 18.8 & 17.8 & 17.0 & 19.9 \\
5 & 13.4 & 10.0 & 10.8 & 12.9 & 23.2 & 22.8 & 26.6 & 30. & 18.3 & 16.5 & 18.7 & 21.7 \\
6 & 10.1 & 9.2 & 13.4 & 15.3 & 22.7 & 25.1 & 28.8 & 32.9 & 16.4 & 17.2 & 21.1 & 24.1 \\
7 & 9.1 & 10.9 & 13.6 & 16.3 & 24.9 & 26.7 & 31.6 & 31.8 & 17.0 & 18.8 & 22.6 & 24.1 \\
8 & 10.8 & 13.9 & 16.5 & 19.1 & 26.6 & 29.4 & 32.8 & 35.5 & 18.7 & 13.9 & 24.7 & 27.3 \\
9 & 13.4 & 13.4 & 18.4 & 21.1 & 28.8 & 31.6 & 33.0 & 34.7 & 21.1 & 22.5 & 25.7 & 27.8 \\
10 & 13.6 & 16.9 & 20.7 & - & 31.6 & 32.6 & 37.2 & - & 22.6 & 24.7 & 28.8 & - \\
11 & 16.7 & 21.3 & - & - & 33.7 & 35.4 & - & - & 25.3 & 25.9 & - & - \\
\hline
\end{tabular}

\section{3-2014}

\begin{tabular}{|c|c|c|c|c|c|c|c|c|c|c|c|c|}
\hline \multirow{2}{*}{$\begin{array}{l}\text { 10-days } \\
(\#)\end{array}$} & \multicolumn{4}{|c|}{ Minimum } & \multicolumn{4}{|c|}{ Maximum } & \multicolumn{4}{|c|}{ Mean } \\
\hline & $\mathrm{D}_{1}$ & $\mathrm{D}_{2}$ & $\mathrm{D}_{3}$ & $\mathrm{D}_{4}$ & $D_{1}$ & $\mathrm{D}_{2}$ & $\mathrm{D}_{3}$ & $\mathrm{D}_{4}$ & $\mathrm{D}_{1}$ & $\mathrm{D}_{2}$ & $\mathrm{D}_{3}$ & $\mathrm{D}_{4}$ \\
\hline 01 & 11.6 & 13.9 & 9.6 & 9.0 & 27.2 & 24.1 & 22.3 & 24.1 & 19.4 & 19.0 & 16.0 & 18.5 \\
\hline 02 & 25.2 & 10.8 & 8.1 & 9.0 & 25.2 & 18.3 & 20.2 & 23.3 & 19.1 & 14.5 & 14.1 & 16.1 \\
\hline 03 & 12.2 & 9.8 & 10.9 & 12.6 & 20.6 & 22.5 & 25.4 & 27.2 & 16.4 & 16.1 & 18.1 & 19.9 \\
\hline 04 & 9.6 & 8.18 & 8.8 & 12.9 & 22.3 & 23.1 & 23.9 & 26.5 & 16.0 & 15.6 & 16.4 & 19.7 \\
\hline 05 & 8.1 & 9.4 & 12.7 & 14.3 & 20.2 & 23.4 & 27.8 & 29.6 & 14.1 & 16.4 & 20.2 & 21.3 \\
\hline 06 & 10.9 & 11.8 & 13.9 & 15.3 & 25.4 & 27.4 & 26.5 & 31.9 & 18.1 & 19.6 & 20.2 & 23.6 \\
\hline 07 & 8.8 & 13.1 & 17.6 & 19.0 & 23.1 & 26.3 & 33.8 & 34.2 & 16.4 & 19.7 & 25.7 & 26.6 \\
\hline 08 & 12.7 & 14.4 & 14.5 & 20.0 & 27.8 & 28.8 & 30.7 & 35.3 & 20.2 & 21.0 & 22.0 & 27.7 \\
\hline 09 & 13.9 & 16.7 & 19.1 & 20.5 & 26.5 & 31.8 & 34.3 & 37.9 & 20.2 & 23.4 & 26.7 & 29.2 \\
\hline 10 & 17.6 & 18.9 & 20.5 & 23.5 & 33.8 & 34.1 & 36.1 & 36.7 & 25.7 & 26.5 & 28.3 & 30.1 \\
\hline 11 & 14.5 & 19.6 & 21.9 & 22.9 & 30.7 & 35.2 & 39.0 & 34.3 & 22.0 & 27.4 & 30.5 & 28.6 \\
\hline 12 & 19.1 & 20.6 & 22.2 & 22.8 & 34.3 & 37.5 & 33.4 & 34.5 & 26.7 & 29.0 & 27.8 & 28.6 \\
\hline 13 & 20.0 & 23.3 & & & 36.7 & 37.1 & & & 28.3 & 30.2 & & \\
\hline 14 & 21.9 & 22.7 & & & 39.0 & 34.1 & & & 30.5 & 28.4 & & \\
\hline 15 & 22.2 & & & & 33.4 & & & & 27 & & & \\
\hline
\end{tabular}

Appendix 2. Average temperature imposed on growth stages of wheat genotypes $(\mathrm{V})$ by sowing times (D) in 2012-13 and 2013-14

\section{Booting 2012-13}

\begin{tabular}{|c|c|c|c|c|c|c|c|c|c|c|c|c|}
\hline \multirow[t]{4}{*}{ V } & \multicolumn{12}{|c|}{ Sowing time } \\
\hline & \multirow{2}{*}{\multicolumn{3}{|c|}{$\begin{array}{l}\text { ITS } \\
\mathrm{D}_{1}\end{array}$}} & \multicolumn{9}{|c|}{ Irrigated Late Sowing (ILS) } \\
\hline & & & & \multicolumn{3}{|c|}{$\mathrm{D}_{2}$} & \multicolumn{3}{|c|}{$\mathrm{D}_{3}$} & \multicolumn{3}{|c|}{$\mathrm{D}_{4}$} \\
\hline & \multicolumn{3}{|c|}{$\frac{\mathrm{D}_{1}}{\operatorname{Max}}$} & Min & Max & Mean & Min & Max & Mean & Min & $\operatorname{Max}$ & Mean \\
\hline V1 & 9.5 & 24.3 & 16.9 & 8.4 & 24.3 & 16.4 & 16.0 & 33.0 & 24.5 & 16.2 & 32.6 & 24.4 \\
\hline V2 & 9.1 & 25.0 & 17.1 & 8.0 & 25.5 & 16.8 & 14.6 & 32.0 & 23.3 & 15.8 & 32.5 & 24.2 \\
\hline V3 & 9.5 & 25.4 & 17.5 & 13.4 & 29.0 & 21.2 & 13.4 & 30.7 & 22.1 & 17.3 & 34.0 & 25.7 \\
\hline V4 & 9.4 & 24.7 & 17.0 & 8.5 & 26.2 & 17.3 & 14.2 & 32.4 & 23.3 & 16.4 & 32.5 & 24.4 \\
\hline
\end{tabular}


Effect of Terminal High Temperature Imposed by Late Sowing on Phenological Traits of Wheat

\begin{tabular}{|c|c|c|c|c|c|c|c|c|c|c|c|c|}
\hline \multirow[t]{4}{*}{ V } & \multicolumn{12}{|c|}{ Sowing time } \\
\hline & \multirow{2}{*}{\multicolumn{3}{|c|}{$\frac{\text { ITS }}{D_{1}}$}} & \multicolumn{9}{|c|}{ Irrigated Late Sowing (ILS) } \\
\hline & & & & \multicolumn{3}{|c|}{$\mathrm{D}_{2}$} & \multicolumn{3}{|c|}{$\mathrm{D}_{3}$} & \multicolumn{3}{|c|}{$\mathrm{D}_{4}$} \\
\hline & Min & Max & Mean & Min & Max & Mean & Min & Max & Mean & Min & Max & Mean \\
\hline \multicolumn{13}{|c|}{ Booting 2013-14 } \\
\hline V1 & 10.69 & 23.43 & 7.06 & 10.8 & 23.38 & 17.08 & 10.9 & 24.69 & 17.81 & 11.72 & 26.36 & 18.9 \\
\hline V2 & 10.30 & 23.30 & 7.05 & 10.96 & 23.69 & 17.33 & 10.78 & 24.50 & 17.64 & 11.8 & 26.46 & 19.11 \\
\hline V3 & 10.61 & 23.48 & 17.05 & 10.9 & 23.52 & 17.12 & 11.17 & 25.17 & 18.08 & 12.01 & 26.80 & 19.40 \\
\hline V4 & 10.69 & 23.43 & 17.06 & 10.8 & 23.38 & 17.08 & 10.9 & 24.69 & 17.81 & 11.8 & 26.69 & 19.30 \\
\hline \multicolumn{13}{|c|}{ Heading 2012-13 } \\
\hline V1 & 9.6 & 26.5 & 18.1 & 18.4 & 29.4 & 23.9 & 14.5 & 31.5 & 23.0 & 17.7 & 29.0 & 23.4 \\
\hline V2 & 8.5 & 25.4 & 17.0 & & 29.3 & 20.9 & 13.2 & 31.2 & 22.2 & 5.0 & 30.6 & 22.8 \\
\hline V3 & 11.0 & 24.5 & 17.7 & & 30.2 & 23.4 & 11.4 & 29.2 & 20.3 & 18.2 & 32.2 & 25.2 \\
\hline V4 & 10.6 & 24.7 & & & 29.8 & 22.6 & 12.3 & 30.5 & 21.4 & 16.7 & 31.4 & 24.1 \\
\hline \multicolumn{13}{|c|}{ Heading 2013-14 } \\
\hline V1 & 10.68 & 23.64 & .16 & 11.09 & 23.67 & 17.38 & 11.11 & 24.99 & 18.05 & 12.22 & 27.13 & 19.68 \\
\hline V2 & 0.68 & 23.64 & & & 23.67 & 17.38 & 1.24 & 25.27 & 18.16 & 12.07 & 26.90 & 9.38 \\
\hline V3 & & 23.87 & & & 23.75 & 17.43 & 11.17 & 25.15 & 18.15 & 12.43 & 27.38 & 19.81 \\
\hline V4 & 10.68 & 23.64 & & & 24.00 & 17.59 & 11.24 & 25.27 & 18.16 & 12.13 & 26.99 & 19.46 \\
\hline \multicolumn{13}{|c|}{ Anthesis 2012-13 } \\
\hline V1 & 10.2 & 28.0 & & & 28.4 & 19.6 & 3.7 & 32.6 & 23.2 & 5.0 & 32.8 & 23.9 \\
\hline $\mathrm{V}_{2}$ & 12.5 & 28.0 & & .4 & 30.7 & 22.1 & 5.6 & 34.4 & 25.0 & 0.3 & 31.5 & 25.9 \\
\hline V3 & & & & & 29.3 & 20.9 & 13.0 & 32.0 & 22.5 & 7.5 & 30.5 & 24.0 \\
\hline $\mathrm{V} 4$ & 8.2 & 24.9 & & 12.9 & 30.4 & 21.6 & 13.7 & 32.4 & 23.0 & 17.9 & 31.2 & 24.5 \\
\hline \multicolumn{13}{|c|}{ Anthesis 2013-14 } \\
\hline V1 & 10.89 & 24.06 & 17.48 & 11.35 & 24.14 & 17.67 & 11.67 & 25.92 & 18.72 & 13.3 & 28.2 & 20.7 \\
\hline $\mathrm{V}$ & 10.82 & 23.95 & & & 23.75 & 17.46 & .23 & 25.20 & 18.13 & 2.6 & 27.5 & 19.9 \\
\hline $\mathrm{V}$ & & .01 & & 11.28 & 24.06 & 17.59 & 11.23 & 25.20 & 18.13 & 12.6 & 27.5 & 19.9 \\
\hline V4 & 10.85 & 23.98 & & 11.2 & 23.86 & 17.53 & 11.19 & 25.13 & 18.08 & 12.6 & 27.5 & 19.9 \\
\hline \multicolumn{13}{|c|}{ Maturity 2012-13 } \\
\hline V1 & 18.6 & 33.0 & & & 36.0 & 29.2 & 21.4 & 35.3 & 28.4 & 23.3 & 35.0 & 29.2 \\
\hline & & & & & 32.8 & 23.3 & 22.6 & & 30.5 & 1.5 & 36.4 & 29.0 \\
\hline V & & & & 21.4 & 36.6 & 29.0 & 20.5 & 38.3 & 29.4 & 19.5 & 35.6 & 27.6 \\
\hline V4 & 17.2 & 34.2 & 25.3 & 21.1 & 33.2 & 27.1 & 21.2 & 37.5 & 29.3 & 19.3 & 34.2 & 26.7 \\
\hline \multicolumn{13}{|c|}{ Maturity 2013-14 } \\
\hline$V_{1}$ & 11.89 & 25.57 & 18.68 & 13.02 & 26.37 & 19.81 & 13.46 & 28.06 & 20.70 & 14.5 & 29.5 & 22.0 \\
\hline$V_{2}$ & 11.84 & 25.48 & 18.61 & 12.74 & 26.30 & 19.46 & 13.36 & 27.97 & 20.61 & 14.5 & 29.5 & 22.0 \\
\hline$V_{3}$ & 12.05 & 25.66 & 18.75 & 13.02 & 26.37 & 19.81 & 13.53 & 28.17 & 20.82 & 14.5 & 29.6 & 22.1 \\
\hline$V_{4}$ & 11.84 & 25.48 & 18.61 & 13.02 & 26.37 & 19.81 & 13.46 & 28.06 & 20.70 & 14.5 & 29.5 & 22.0 \\
\hline
\end{tabular}

ITS: Irrigated Timely Sowing, $\mathrm{D}_{1}$ : Nov 25, $\mathrm{D}_{2}$ : Dec 10, $\mathrm{D}_{3}$ : Dec 25 and $\mathrm{D}_{4}$ : Jan 10 